\title{
THE OPTIMATION SIMULTANEUOS DETERMINATION OF LEAD(II) AND CADMIUM(II) BY ADSORPTIVE STRIPPING VOLTAMMETRY (ADSV)
}

\author{
Deswati, Hamzar Suyani, Umiati Loekman, and Nilam Sari \\ Department of Chemistry, Faculty of Mathematics and Natural Sciences, \\ Andalas University, Kampus Unand Limau Manis Padang \\ Email : deswati_ua@yahoo.co.id
}

\begin{abstract}
A selective and sensitive adsorptive stripping voltammetric (AdSV) method for simultaneous determination of lead(II) and cadmium(II) were proposed. The aim of this study was to get the optimum condition for simultaneuos determination of lead(II) and cadmium(II). The parameters were studied such as: variation of accumulation potential, accumulation time, $\mathrm{pH}$, and variation of calcon concentration. In this case, the optimum conditions were reached at accumulation potential $-0.7 \mathrm{~V}$, accumulation time $80 \mathrm{~s}$, concentration of $0.12 \mathrm{mM}$ calcon, and $\mathrm{pH} 7.0$. At the optimum conditions the relative standard deviation were $2.90 \%$ and $1.46 \%$ for $\mathrm{Pb}(\mathrm{II})$ and $\mathrm{Cd}$ (II) respectively for eight replicates $(n=8)$ measurements. The method was applied for the direct determination of $\mathrm{Pb}$ (II) and $\mathrm{Cd}(\mathrm{II})$ in sea water around Bungus, Padang City. Concentration $\mathrm{Pb}$ (II) and $\mathrm{Cd}$ (II) in sample were $9.918 \mathrm{~g} / \mathrm{L}-27.320 \mathrm{~g} / \mathrm{L}$ for $\mathrm{Pb}$ (II) and $7.997 \mu \mathrm{g} / \mathrm{L}-32.521 \mathrm{~g} / \mathrm{L}$ for $\mathrm{Cd}(\mathrm{II})$, with recovery of $99.48 \%$, and 103.28 for $\mathrm{Pb}(\mathrm{II})$, and $\mathrm{Cd}(\mathrm{II})$ respectively.
\end{abstract}

Keywords : Lead, cadmium, adsorptive, stripping, voltammetry, simultaneous

\section{PENDAHULUAN}

Dampak negatif dari pertumbuhan industri serta pemukiman yang cukup pesat adalah bertambahnya jumlah logam berat beracun di lingkungan. Beberapa unsur yang termasuk dalam kategori logam berat seperti: $\mathrm{As}, \mathrm{Cr}, \mathrm{Cd}$, $\mathrm{Pb}, \mathrm{Fe}, \mathrm{Cu}, \mathrm{Co}, \mathrm{Hg}, \mathrm{Se}, \mathrm{Sb}, \mathrm{Mn}, \mathrm{Zn}$, dan $\mathrm{Ni}$ berasal dari limbah industri dan hasil aktivitas penduduk, khususnya di kota besar. Adanya logam-logam berat dalam lingkungan termasuk bahan makanan sangat berbahaya karena mempunyai tingkat toksisitas yang tinggi ${ }^{[1]}$.

Apabila masuk ke dalam tubuh manusia mempunyai kecenderungan berkumpul dalam organ tubuh dan tidak bisa keluar lagi melalui proses pencernaan. Air, tanah, dan udara adalah media yang dapat digunakan untuk penyebaran logam berat ke lingkungan. Tanaman yang berdaun lebar disamping menyerap logam berat dari tanah juga dapat menyerap logam berat dari udara ${ }^{[2]}$.

Permasalahan dalam penelitian ini adalah karena ion-ion logam berat $\mathrm{Pb}$ dan $\mathrm{Cd}$ dalam perairan sangat berbahaya, yang bersifat toksik sehingga merusak lingkungan dan kehidupan biota dari perairan tersebut jika kadarnya telah melampaui ambang batas yang ditetapkan. Diketahui kadar ion-ion logam tersebut dalam perairan dan dalam bahan lingkungan, baik tanah, batuan maupun bahan biologi sangat kecil sekali (runut) dalam orde $\mathrm{ng} / \mathrm{kg}$ sampai dengan $\mathrm{mg} / \mathrm{kg}$, sementara matrik sampel (misalnya kadar garam dalam air laut) cukup besar dan juga terikat dalam matrik yang kompleks.

Metode yang ada untuk analisis ion-ion logam diantaranya metode Flame Atomic Absorption Spectrometry (FAAS), metode inductively coupled plasma-atomic emision spectrophotometry (ICP-AES). Namun, kedua metode ini membutuhkan biaya yang mahal dan kurang praktis. Selain itu, juga tidak dapat mengukur kadar ion-ion logam yang sangat kecil $^{[3]}$. Walaupun sebelumnya telah dilakukan prekonsentrasi (pemekatan) untuk mengurangi atau menghilangkan kadar garam yang cukup tinggi dari sampel berupa air laut dengan menggunakan metode ekstraksi pelarut ${ }^{[4]}$. Oleh 
sebab itu, diperlukan suatu metode alternatif yang dapat mengatasi keterbatasan kedua metode tersebut.

Voltammetri dipilih sebagai metode alternatif karena memiliki banyak kelebihan, antara lain: kadar garam yang tinggi dari air laut tidak mengganggu dalam analisis, memiliki sensitivitas tinggi, limit deteksi rendah pada skala $\mathrm{g} / \mathrm{L}(\mathrm{ppb})$, penggunaan dan preparasi sampel yang mudah, analisis cepat, dan infrastruktur yang murah ${ }^{[5-7]}$. Disamping itu, dengan metode ini dimungkinkan mempelajari spesi kimia dari logam berat ${ }^{[8]}$, yang tidak bisa dilakukan dengan metode lain. Metode ini bisa dilakukan untuk penentuan secara simultan $\mathrm{Cu}$ dan $\mathrm{Pb}$ dalam air laut dengan menggunakan kalkon sebagai pengompleks ${ }^{[9]}$, penentuan simultan $\mathrm{Cu}, \mathrm{Bi}$, dan $\mathrm{Pb}$ secara voltammetri stripping adsorptif dengan pengomplek thymolphthalexone ${ }^{[10]}$, dan penentuan simultan $\mathrm{Ni}$ dan $\mathrm{Cd}$ secara differensial pulse polarografi $i^{[11]}$. Toksisitas logam berat ditentukan dari spesi kimianya ${ }^{[3,12]}$. Hampir semua metode penentuan logam dalam jumlah yang sangat kecil memerlukan waktu yang cukup lama pada tahap prekonsentrasi sebelum pengukuran. Pada Voltammetri Stripping Adsorptif tahap prekonsentrasinya waktunya lebih singkat, umumnya kurang dari 1 menit $^{[13]}$.

Permasalahan yang lain dari penelitian ini adalah metode analisis untuk penentuan $\mathrm{Pb}$ dan $\mathrm{Cd}$ secara simultan dalam air laut dengan voltammetri stripping adsorptif belum ditemukan kondisi yang cocok.

Tujuan dari penelitian ini adalah untuk mendapatkan kondisi optimum pengukuran dari ion logam $\mathrm{Pb}$ dan $\mathrm{Cd}$ secara simultan sehingga dapat diaplikasikan untuk analisis logam $\mathrm{Pb}$ dan $\mathrm{Cd}$ dalam air laut. Untuk mencapai tujuan tersebut dipelajari parameterparameter berikut: variasi potensial akumulasi, waktu akumulasi, $\mathrm{pH}$, dan variasi konsentrasi kalkon sebagai pengompleks. Untuk menentukan ketelitian metode ditentukan standar deviasi relatif (SDR), perolehan kembali (recovery) dan batas deteksi (limit deteksi).

\section{METODOLOGI PENELITIAN}

\section{Alat dan Bahan}

Alat yang digunakan dalam penelitian ini adalah Methrom 797 Computrace dengan elektroda kerja HMDE, elektroda pembanding berupa $\mathrm{Ag} / \mathrm{AgCl} / \mathrm{KCl} 3 \mathrm{M}$, dan elektroda $\mathrm{Pt}$ sebagai elektroda pendukung, $\mathrm{pH}$ meter Griffin model 80, Griffin dan Loughbrough, Inggris, dan neraca analitis Mettler AE 200, Toledo OH-USA, serta peralatan gelas yang biasa digunakan di laboratorium. Bahan yang digunakan antara lain $\mathrm{Pb}\left(\mathrm{NO}_{3}\right)_{2}, \mathrm{Cd}\left(\mathrm{NO}_{3}\right)_{2}$, gas $\mathrm{N}_{2}$, kalkon, elektrolit pendukung $\mathrm{KCl}$, buffer asetat, metanol, $\mathrm{HNO}_{3} 65 \%$, akuabides, dan sampel berupa air laut.

\section{Prosedur Kerja}

\section{Pengaruh potensial akumulasi terhadap kondisi optimum pengukuran}

Masing-masing $5 \mathrm{~mL}$ larutan standar $\mathrm{Pb}$ (II) 50 $\mu \mathrm{g} / \mathrm{L}$ dan $5 \mathrm{~mL}$ larutan standar Cd(II) $50 \mu \mathrm{g} / \mathrm{L}$ dipipet ke dalam vessel voltammeter, ditambahkan $0,5 \mathrm{~mL}$ larutan elektrolit $0,1 \mathrm{M}$, kemudian ditambahkan $0,3 \mathrm{~mL}$ kalkon 0,1 $\mathrm{mM}$. Potensial akumulasi diatur dari $-0,9$ sampai $-0,3 \mathrm{~V}$. Dilakukan pengukuran untuk mendapatkan nilai arus puncak (Ip). Dialurkan kurva antara variasi potensial akumulasi dengan arus puncak (Ip) untuk mendapatkan kondisi optimum pengukuran. Potensial akumulasi optimum digunakan untuk penyelidikan selanjutnya.

\section{Pengaruh waktu akumulasi terhadap kondisi optimum pengukuran}

Masing-masing $5 \mathrm{~mL}$ larutan standar $\mathrm{Pb}$ (II) 50 $\mu \mathrm{g} / \mathrm{L}$ dan $5 \mathrm{~mL}$ larutan standar Cd(II) $50 \mu \mathrm{g} / \mathrm{L}$ dipipet ke dalam vessel voltammeter, ditambahkan $0,5 \mathrm{~mL}$ larutan elektrolit $0,1 \mathrm{M}$ kemudian ditambahkan $0,3 \mathrm{~mL}$ kalkon 0,1 $\mathrm{mM}$. Potensial akumulasi diatur sesuai dengan kondisi optimum yang telah diperoleh. Waktu akumulasi diatur dari 30 detik sampai 120 detik. Dilakukan pengukuran untuk mendapatkan nilai arus puncak. Selanjutnya dialurkan kurva antara variasi waktu akumulasi dengan arus puncak (Ip) untuk mendapatkan kondisi optimum pengukuran. Waktu 
akumulasi optimum digunakan untuk penyelidikan selanjutnya.

\section{Pengaruh konsentrasi kalkon terhadap kondisi optimum pengukuran}

Masing-masing $5 \mathrm{~mL}$ larutan standar $\mathrm{Pb}$ (II) 50 $\mu \mathrm{g} / \mathrm{L}$ dan $5 \mathrm{~mL}$ larutan standar Cd(II) $50 \mu \mathrm{g} / \mathrm{L}$ dipipet ke dalam vessel voltammeter, ditambahkan 0,5 mL larutan elektrolit dengan konsentrasi optimum yang telah diperoleh, kemudian ditambahkan kalkon 0,3 mL. Potensial akumulasi dan waktu akumulasi diatur pada kondisi optimum yang diperoleh. Konsentrasi kalkon yang dipakai divariasikan pada 0,$02 ; 0,04 ; 0,06 ; 0,08 ; 0,1 ; 0,12 ; 0,14$; dan $0,16 \mathrm{mM}$. Dilakukan pengukuran untuk mendapatkan nilai arus puncak. Selanjutnya, dialurkan kurva antara variasi konsentrasi kalkon dengan arus puncak (Ip) untuk mendapatkan kondisi optimum pengukuran. Konsentrasi optimum digunakan untuk penyelidikan selanjutnya.

\section{Pengaruh pH terhadap kondisi optimum pengukuran}

Masing-masing $5 \mathrm{~mL}$ larutan standar $\mathrm{Pb}$ (II) 50 $\mu \mathrm{g} / \mathrm{L}$ dan $5 \mathrm{~mL}$ larutan standar Cd(II) $50 \mu \mathrm{g} / \mathrm{L}$ dipipet ke dalam vessel voltammeter, ditambahkan $0,5 \mathrm{~mL}$ larutan elektrolit dan 0,3 $\mathrm{mL}$ kalkon sesuai dengan konsentrasi optimum yang telah diperoleh. Potensial akumulasi dan

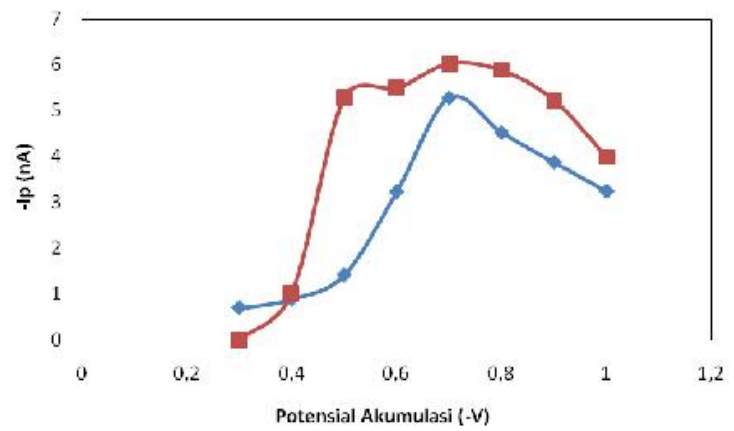

Gambar 1. Kurva hubungan potensial akumulasi (-V) vs arus puncak (Ip)

Kondisi pengukuran: larutan standar $\mathrm{Pb}$ (II) 50 $\mathrm{g} / \mathrm{L}(\leftarrow)$; larutan standar Cd(II) $50 \mathrm{~g} / \mathrm{L}(-\mathbf{-})$ $\mathrm{KCl} \mathrm{0,1} \mathrm{M;} \mathrm{kalkon} \mathrm{0,1} \mathrm{mM}$; pH 4; waktu akumulasi 60 detik; dan scan rate $-0,25 \mathrm{~V}$ hingga $-0,7 \mathrm{~V}$ waktu akumulasi diatur sesuai dengan kondisi optimum yang telah diperoleh. $\mathrm{pH}$ diatur pada range 2 - 9 dengan penambahan larutan buffer. Dilakukan pengukuran untuk mendapatkan nilai arus puncak. Selanjutnya, dialurkan kurva antara variasi $\mathrm{pH}$ dengan arus puncak (Ip) untuk mendapatkan kondisi optimum pengukuran. $\mathrm{pH}$ optimum digunakan untuk penyelidikan selanjutnya.

\section{HASIL DAN PEMBAHASAN}

\section{Kondisi Optimum Pengukuran}

Pada penelitian ini dilakukan penentuan $\mathrm{Pb}$ (II) dan $\mathrm{Cd}(\mathrm{II})$ secara simultan dengan Voltammetri Stripping Adsorptif (AdSV). Penentuan kondisi optimum telah dilakukan terhadap variabel berikut yaitu variasi potensial akumulasi, waktu akumulasi, konsentrasi kalkon, dan variasi pH larutan.

\section{Pengaruh variasi potensial akumulasi terhadap arus puncak}

Pengaruh potensial akumulasi terhadap kondisi optimum pengukuran telah dilakukan mulai dari potensial akumulasi -0,3 V sampai -1,0 V.

Potensial akumulasi adalah potensial pada saat analit terakumulasi atau terdeposisi pada permukaan elektroda kerja.

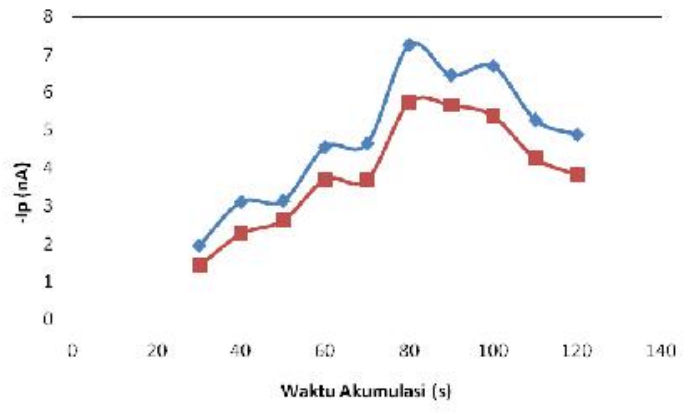

Gambar 2. Kurva hubungan waktu akumulasi (s) vs arus puncak (Ip)

Kondisi pengukuran: larutan standar $\mathrm{Pb}$ (II) 50 $\mathrm{g} / \mathrm{L}(\leadsto)$; larutan standar Cd(II) $50 \mathrm{~g} / \mathrm{L}(\boldsymbol{-})$ $\mathrm{KCl} 0,1 \mathrm{M}$; kalkon $0,1 \mathrm{mM}$; $\mathrm{pH} 4$; potensial akumulasi $-0,7 \mathrm{~V}$; dan scan rate $-0,25 \mathrm{~V}$ hingga $-0,7 \mathrm{~V}$ 


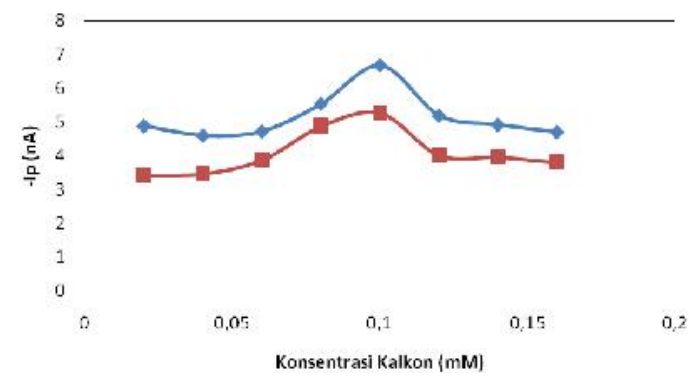

Gambar 3. Kurva hubungan konsentrasi kalkon (mM) vs arus puncak (Ip)

Kondisi pengukuran: larutan standar $\mathrm{Pb}$ (II) $50 \mathrm{~g} / \mathrm{L}(\leadsto)$; larutan standar Cd(II) $50 \mathrm{~g} / \mathrm{L}$ (-7, $\mathrm{KCl} 0,12 \mathrm{M}$; pH 4; waktu akumulasi 80 detik; potensial akumulasi $-0,7 \mathrm{~V}$; dan scan rate $-0,25 \mathrm{~V}$ hingga $-0,7 \mathrm{~V}$

Pada Gambar 1 dapat dilihat arus puncak meningkat seiring dengan meningkatnya potensial ke arah potensial yang lebih negatif. Saat pertukaran potensial $-0,8 \mathrm{~V}$ hingga $-1 \mathrm{~V}$ arus puncak berkurang. Hal ini menunjukkan semua analit telah terdeposisi di permukaan elektroda pada potensial akumulai $-0,7 \mathrm{~V}$. Dengan demikian, potensial akumulasi pada potensial $-0,7 \mathrm{~V}$ dipilih sebagai potensial akumulasi optimum pengukuran dan digunakan untuk penelitian selanjutnya.

\section{Pengaruh variasi waktu akumulasi terhadap arus puncak}

Waktu akumulasi merupakan waktu pada saat analit terdeposisi pada permukaan elektroda merkuri. Hasil pengukurannya dapat dilihat pada Gambar 2 dimana pengaruh waktu akumulasi terhadap arus puncak dengan keberadaan kalkon sebagai pengompleks. Awalnya arus puncak meningkat mulai dari waktu akumulasi 30 detik hingga 80 detik. Secara teori, semakin lama waktu akumulasi maka semakin banyak analit yang terdeposisi ke permukaan elektroda merkuri sehingga pada saat stripping dihasilkan arus yang besar ${ }^{[14]}$. Namun setelah waktu akumulasi 80 detik arus puncak menurun. Hal ini disebabkan karena terjadi kejenuhan pada permukaan elektroda, sehingga pada saat stripping tidak semua analit terlepas dari permukaan elektroda yang mengakibatkan arus yang dihasilkan semakin kecil.

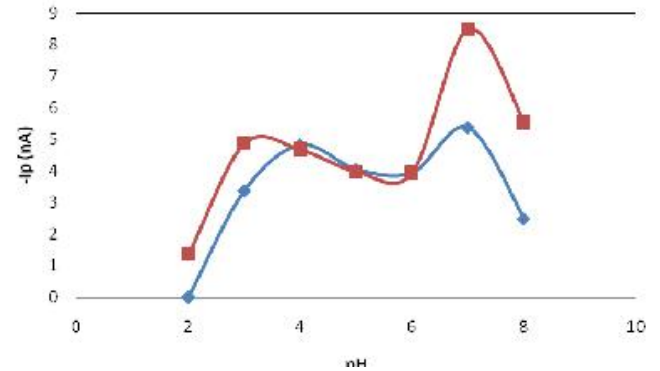

Gambar 4. Kurva hubungan $\mathrm{pH}$ larutan vs arus puncak (Ip)

Kondisi pengukuran: larutan standar $\mathrm{Pb}$ (II) $50 \mathrm{~g} / \mathrm{L}(\nrightarrow)$; larutan standar Cd(II) $50 \mathrm{~g} / \mathrm{L}$ (-); $\mathrm{KCl} 0,12 \mathrm{M}$; kalkon 0,1 mM; waktu akumulasi 80 detik; potensial akumulasi $0,7 \mathrm{~V}$; dan scan rate $-0,25 \mathrm{~V}$ hingga $-0,7 \mathrm{~V}$

\section{Pengaruh variasi konsentrasi kalkon terhadap arus puncak}

Kalkon berfungsi sebagai pengompleks yang akan membentuk kompleks dengan logam. Ia berperan sebagai basa Lewis yang menyumbangkan pasangan elektron sunyi pada ion logam. Kestabilan kompleks akan menentukan jumlah analit yang terdeposisi pada permukaan elektroda kerja. Kompleks yang stabil dengan ion logam akan menghasilkan arus puncak yang tinggi. Dalam penelitian ini dipilih kalkon sebagai pengompleks didasarkan pada penelitian sebelumnya $^{[5]}$, dimana telah dilakukan pengukuran variasi pengompleks dan diperoleh hasil optimum untuk kompleks yang dipakai yaitu kalkon. Artinya, kalkon memiliki keselektifan yang tinggi terhadap logam $\mathrm{Pb}$ (II) dan $\mathrm{Cd}(\mathrm{II})$.

Penentuan konsentrasi optimum kalkon dilakukan pada variasi konsentrasi 0,$02 ; 0,04$; 0,$06 ; 0,08 ; 0,1 ; 0,12 ; 0,14$; dan $0,16 \mathrm{mM}$. Hasilnya dapat dilihat pada Gambar 3.pada Gambar 3 terlihat bahwa arus meningkat pada rentang konsentrasi $0,02 \mathrm{mM}$ sampai $0,1 \mathrm{mM}$. Namun pada rentang konsentrasi $0,12 \mathrm{mM}$ sampai $0,16 \mathrm{mM}$ terjadi penurunan arus. Berdasarkan hal tersebut, konsentrasi $0,1 \mathrm{mM}$ dipilih sebagai kondisi optimum dalam penentuan konsentrasi kalkon dan digunakan untuk perlakuan selanjutnya. 


\section{Pengaruh variasi pH terhadap arus puncak}

Dalam penentuan kondisi optimum selanjutnya dilakukan optimasi terhadap pH larutan. Dalam pengukuran ini, $\mathrm{pH}$ merupakan parameter yang sangat penting karena berkaitan dengan pembentukan senyawa kompleks antara kalkon dengan logam $\mathrm{Pb}$ (II) dan $\mathrm{Cd}(\mathrm{II})$. Ia berperan dalam meningkatkan kestabilan kompleks yang terbentuk. Optimasi penentuan $\mathrm{pH}$ dilakukan pada rentang $\mathrm{pH} 2$ - 8. Hasilnya dapat dilihat pada Gambar 4.

Pada rentang $\mathrm{pH} 2-3$ terjadi kenaikan arus yang signifikan. Hal ini menandakan semakin banyak kompleks yang terakumulasi pada permukaan elektroda. Namun pada rentang $\mathrm{pH}$ $4-6$ terjadi perubahan arus yang tidak terlalu besar, namun saat $\mathrm{pH} \mathrm{7,} \mathrm{arus} \mathrm{meningkat} \mathrm{secara}$ signifikan. Berdasarkan kurva di atas, $\mathrm{pH}$ optimum yang diperoleh adalah 7 dan dipakai untuk perlakuan selanjutnya.

\section{Aplikasi metode}

Dari kondisi optimum pengukuran yang telah didapatkan di atas, metode ini diaplikasikan untuk penentuan $\mathrm{Pb}$ (II) dan $\mathrm{Cd}(\mathrm{II})$ secara lansung dalam air laut sekitar Bungus, Kota Padang. Konsentrasi sampel yang diperoleh adalah: 9,918 g/L $-27,320$ g/L untuk $\mathrm{Pb}$ (II) dan 7,997 g/L - 32,521 g/L untuk Cd(II), dengan nilai perolehan kembali (recovery) untuk $\mathrm{Pb}$ (II) dan $\mathrm{Cd}$ (II) adalah $99,48 \%$ dan $103,28 \%$.

\section{KESIMPULAN}

Dari hasil penelitian dapat disimpulkan kondisi optimum pengukuran timbal(II) dan kadmium(II) secara simultan dengan voltammetri stripping adsorptif yaitu: potensial akumulasi $-0,7 \mathrm{~V}$, waktu akumulasi 80 detik, konsentrasi kalkon $0,12 \mathrm{mM}$, dan $\mathrm{pH}$ larutan 7,0. Pada kondisi optimum tersebut diperoleh standar deviasi relatif dengan delapan kali pengulangan $(\mathrm{n}=8)$, untuk $\mathrm{Pb}(\mathrm{II})$ adalah $2,90 \%$ dan $\mathrm{Cd}(\mathrm{II}) \quad 1,46 \%$. Metode ini diaplikasikan untuk penentuan $\mathrm{Pb}(\mathrm{II})$ dan Cd(II) secara lansung dalam air laut sekitar Bungus, Kota Padang. Konsentrasi sampel yang diperoleh adalah: 9,918 $\mathrm{g} / \mathrm{L}-27,320$ $\mathrm{g} / \mathrm{L}$ untuk $\mathrm{Pb}(\mathrm{II})$ dan 7,997 $\mathrm{g} / \mathrm{L}-32,521$ $\mathrm{g} / \mathrm{L}$ untuk $\mathrm{Cd}(\mathrm{II})$, dengan nilai perolehan kembali (recovery) untuk $\mathrm{Pb}$ (II) dan $\mathrm{Cd}$ (II) adalah $99,48 \%$ dan $103,28 \%$.

\section{Ucapan Terima Kasih}

Kami mengucapkan ribuan terima kasih kepada : 1). Direktorat Jenderal Pendidikan Tinggi, Kementerian Pendidikan dan Kebudayan yang telah membiayai penelitian ini, sesuai dengan Surat Perjanjian Pelaksanaan Penugasan Penelitian Fundamental Nomor: 169/SP2H/PL/Dit.Litmas/IV/2011, tanggal 14 April 2011, 2). Lembaga penelitian Universitas Andalas yang telah memfasilitasi sehingga penelitian berjalan sesuai jadwal yang ditetapkan.

\section{DAFTAR PUSTAKA}

1. H. S. Sanusi. S. Syamsu, dan S. Sardjirun, Kandungan dan distribusi logam berat pada berbagai komoditi ikan laut disalurkan lewat TPI Pasar Ikan Jakarta, Skripsi Fakultas Perikanan Institut Pertanian Bogor, (1985).

2. Saryati dan S. Wardiyati, Aplikasi voltammetri untuk penentuan logam berat dalam bahan lingkungan, Indo. J. Mat. Sci., edisi khusus Desember : 265-270, (2008).

3. J. C. Richard. J. B. Martin, and T. Milton, Analytical technique for trace element analysis :an Overview, Trend in Anal. Chem., 24(3), 266 - 274, (2005).

4. Deswati, Penggunaan sand filter dalam rangka memperbaiki kualitas air dan meminimalisasi kandungan logam berat di perairan Balai Benih Ikan Pantai (BBIP) Teluk Buo, Dampak., 7(2), 26 - 33, (2010).

5. Deswati, H. Suyani, and Safni, The Method of the development of analysis $\mathrm{Cd}, \mathrm{Cu}, \mathrm{Pb}$ and $\mathrm{Zn}$ in sea water by adsorptive stripping voltammetry (AdSV) in the presence of calcon as complexing agent, Indo. J. Chem., 12(1), $20-27$, (2012).

6. A. A. Ensafi, S. Abbasi, and H. R. Mansour, Differential pulse adsorption stripping voltammetric determination of copper(II) with 2-mercaptobenzimidazol 
at Hanging Mercury-Drop Electrode, Anal. Sci., 17, 609-612, (2001).

7. S. Zang and W. Huang, Simultaneous determination of $\mathrm{Cd}(\mathrm{II})$ and $\mathrm{Pb}$ (II) using a chemically modified electrode, Anal. Sci., 17, 983-985, (2001).

8. Deswati, H. Suyani, Imelda, dan Yulia, Studi optimasi penentuan Cr(VI) dalam air laut secara voltammetri stripping adsorptif, J. Ris. Kim., 3(1), 22-30, (2009).

9. Deswati, H. Suyani, dan Hilfi, Penentuan timbal dan tembaga dalam air laut dengan simultan dengan menggunakan kalkon sebagai pengomplek secara voltammetri stripping adsorptif, Proseding Seminar Nasional Himpunan Kimia Indonesia, 22 Oktober di Padang, (2011).

10. A. Babaei. I. Shams, and A. Samadzadeh Simultaneous determination of copper, bismuth and lead by adsorptive stripping voltammetry in the presence of thymolphthalexone, Anal. Sci., 22, 955959, (2006).

11. R. M. Mondragon, A. Baeza, and J. G. Ibanez, Simultaneous determination of nickel and cadmium by differential pulse polarography, Anal. Sci., 18, 191-193, . A., (2006).

12. P. Proti, Introduction to modern voltammetric and polarographic analysis techniques, Amel Electrochemistry Ed. IV, 2001.

13. M. K. Amini and M. Kabiri, Determination of trace amounts of nickel by differential pulse adsorptive cathodic stripping voltmmetry using calconcarboxylic acid as a chelating agent, J. Iran. Chem Soc., 2, 32-39, (2005).

14. J. Wang, Analytical Electrochemistry, $2^{\text {nd }}$ -ed, A John Willey and Sons, Inc., Publication, New York, 2000, 81-84 and 108-110. 